\title{
Alcohol Metabolism and Toxicity: Role of Cytochrome $P-450^{1}$
}

\author{
Minor J. CoOn, Dennis R. Koop, Lorraine E. ReEve, and Becky L. CRump
}

Department of Biological Chemistry, Medical School, The University of Michigan, Ann Arbor, Michigan 48109

\begin{abstract}
Alcohol Metabolism and Toxicity: Role of Cytochrome P-450. CoON, M. J., KooP, D. R., ReEve, L. E., AND CRump, B. L. (1984). Fundam. Appl. Toxicol. 4, 134-143. A new isozyme of cytochrome $P-450$, designated form $3 \mathrm{a}$ on the basis of its relative electrophoretic mobility, has been purified to homogeneity from liver microsomes of rabbits treated chronically with ethanol. This cytochrome has the highest activity of the known rabbit $P-450$ isozymes in the oxidation of ethanol to acetaldehyde. In view of the reports of others that the hepatotoxicity of acetaminophen is increased in ethanol-treated animals and the human alcoholic, we have determined the activity of the six available $P-450$ isozymes in the activation of the drug to give an intermediate which forms a conjugate with reduced glutathione. Isozymes $3 a, 4$, and 6 , the three major forms of cytochrome $P-450$ present in liver microsomes from rabbits chronically treated with ethanol, exhibited the highest activities in the reconstituted enzyme system, whereas isozymes $3 \mathrm{~b}$ and $3 \mathrm{c}$ were 10 - to 20 -fold less effective and phenobarbital-inducible isozyme 2 was essentially inactive, even in the presence of cytochrome $b_{5}$. The results obtained thus indicate that induction by ethanol of $P-450$ isozyme 3a may contribute to the toxicity of acetaminophen but that other cytochromes also play a significant role.
\end{abstract}

Involvement of liver microsomal enzymes in ethanol oxidation and toxicity. In a brief historical review on the physiological combustion of alcohol, Theorell (1974) concluded some years ago that the main pathway is catalyzed by alcohol dehydrogenase but that alternate pathways exist, and stated that "alcohol and man is an old problem." Unfortunately, the very serious problem of alcoholism is growing instead of abating. This laboratory is presently studying a possible alternate pathway of alcohol oxidation involving cytochrome $P-450$ and the effect of ethanol on $P-450$-catalyzed reactions in which foreign compounds are sometimes detoxified and in other instances made more toxic, mutagenic, or carcinogenic. Such studies may provide basic information on alcohol metabolism and may also contribute to an understanding of the genetic factors (Deitrich and Collins, 1974) and various med-

\footnotetext{
${ }^{1}$ Presented at the Symposium on Alcohol Metabolism and Hepatotoxicity, 22nd Annual Meeting of the Society of Toxicology, Las Vegas, Nevada, March 7-11, 1983.
}

ical problems (Majchrowicz and Noble, 1979) associated with alcoholism.

Cytochrome $P-450$ represents a group of hemoproteins unique in having a sulfur atom ligated to the iron which forms $\mathrm{CO}$ complexes with a Soret band at about $450 \mathrm{~nm}$. Liver microsomes are particularly rich in $P-450$ that oxygenates or otherwise modifies physiologically occurring lipids such as fatty acids, prostaglandins, and steroids as well as a host of foreign compounds, including drugs, petroleum products, anesthetics, insecticides, and carcinogens. No attempt will be made to discuss here the structure and function of $P-450$ in detail, but it should be noted that at least 10 distinct isozymes have been isolated from rabbit and from rat liver microsomes. There are hundreds, perhaps thousands of substrates, for which the isozymes exhibit only partial selectivity; the number of inducers of $P-450$ enzymes is also very great and includes drugs, carcinogens, halogenated substances, and so forth. The progress in this rapidly developing field has been described in recent reviews and 
proceedings of symposia, (Guengerich, 1979; White and Coon, 1980; Lu and West, 1980; Coon, 1981; Coon and Koop, 1983; Coon and White, 1980; Coon et al., 1980a; Gustafsson et al., 1980; Sato and Kato, 1982).

The catalase pathway for ethanol oxidation by $\mathrm{H}_{2} \mathrm{O}_{2}$ in peroxisomes (Keilin and Hartree, 1945; Chance, 1947; Lazarow, 1977) is apparently of minor significance in ethanol metabolism in vivo (Smith, 1961). The existence of a distinct microsomal ethanol-oxidizing system independent of contaminating catalase has been the subject of much controversy (Estabrook, 1974), with Lieber et al. (1974) as proponents and a number of other investigators (Oshino et al., 1974; Thurman et al., 1974; Isselbacher and Carter, 1974; Vatsis and Schulman, 1974) as skeptics armed with contrary data. Rubin et al. (1977) found that the proposed system was absent from a transplantable hepatocellular carcinoma owing to low activities of NADPH-cytochrome $c$ reductase and the oxidase, but was apparently present in the well-differentiated tumor, thus indicating the complexity of the system. Our laboratory (Vatsis and Coon, 1977) reported some years ago that the phenobarbital- and benzoflavone-inducible forms of purified rabbit liver microsomal $P-450$ (designated as $P-450_{\mathrm{LM}_{2}}$ and $P-450_{\mathrm{LM}_{4}}$ or isozymes 2 and 4 , respectively, on the basis of their relative electrophoretic mobilities) did not catalyze significant rates of ethanol oxidation, whereas Miwa et al. (1978) observed acetaldehyde formation with purified $P-450$ isozymes from several species. Other investigators (Werringloer et al., 1977; Vatsis and Schulman, 1977; Vatsis et al., 1977; Brentzcl and Thurman, 1977) have provided evidence against the concept of a microsomal ethanol-oxidizing system.

The possible role of $P-450$ in the oxidation of ethanol and other aliphatic alcohols has been the subject of much debate. Alcohol oxidation in reconstituted enzyme systems by known inducible $P-450$ isozymes from several species has been studied with varying conclusions (Vatsis and Coon, 1977; Miwa et al.,
1978; Coon et al., 1980b; Ingelman-Sundberg and Johansson, 1981). The effects of chronic ethanol administration to rats include proliferation of the hepatic smooth endoplasmic reticulum and an increase in the $P-450$ content and rate of hydroxylation of aniline and oxidation of alcohols in microsomes (Iseri et al., 1966; Lieber and DeCarli, 1970; Ishii et al., 1973; Villeneuve et al., 1976; Ohnishi and Lieber, 1977a; Sharma et al., 1979; Morgan et al., 1981; Teschke et al., 1981). An ethanolmediated increase in $P-450$ in cultured chick embryo hepatocytes has also been reported (Sinclair et al., 1981). In the rat both normal alcohol metabolism (Mezey et al., 1973) and the enhanced rate after induction have been attributed to a hepatic microsomal system distinct from the known systems involving alcohol dehydrogenase and catalase (Lieber and DeCarli, 1970). The increased microsomal activity as a result of ethanol treatment was thought to be due to an enhanced content of one or more forms of $P-450$ (Villeneuve et al., 1976; Ohnishi and Lieber, 1977b; Morgan et al., 1981; Mungikar et al., 1980). Comai and Gaylor (1973) first reported that pretreatment of rats with phenobarbital, 3-methylcholanthrene, and ethanol yielded cytochrome fractions with different affinities for cyanide. Several years later Ohnishi and Lieber (1977a) described an increase in two proteins following ethanol treatment and solubilized and reconstituted the microsomal ethanol-oxidizing activity, and Joly and co-workers (Villeneuve $e t$ al., 1976; Mungikar et al., 1980) reported the partial purification of an isozyme with high activity toward both ethanol and aniline, but presented no evidence for the isolation of a single isozyme. An electrophoretically homogeneous enzyme was obtained from liver microsomes of pigs treated with ethanol (Tsuji et al., 1980), but the immunochemical crossreactivity of this cytochrome with other forms indicated that it was apparently not a unique $P-450$; furthermore, the aniline hydroxylase activity was not high, and the ethanol-oxidizing activity was not reported.

Clearly, the isolation and characterization 
of a highly purified $P-450$ isozyme that is enhanced by ethanol treatment of the animals and has significant ethanol-metabolizing activity, as recently achieved in this laboratory (Koop et al., 1982; Morgan et al., 1982; Coon et al., 1983), were essential to progress in this controversial field. That the observed ethanoloxidizing activity of our rabbit $P-450_{\mathrm{LM}_{3 \mathrm{a}}}$ is not due to contaminating catalase or alcohol dehydrogenase was shown by several lines of evidence. $\mathrm{LM}_{3 \mathrm{a}}$ is isolated as an electrophoretically homogeneous preparation; the ethanol-oxidizing activity displays all the characteristics of a typical $P-450$-catalyzed reaction, including requirements for NADPH, reductase, and phospholipid. Catalatic activity in the preparation could not be detected, and ethanol oxidation was not inhibited by azide. Moreover, catalase has little activity toward two alcohols known to be substrates for $P-450_{\mathrm{LM}_{3 \mathrm{a}}}$, propanol and butanol (Chance, 1947). Since oxidized pyridine nucleotides could not support the reaction, significant $\mathrm{ADH}$ activity can also be excluded.

As reviewed by Mezey (1976) and Lieber (1980), ethanol-drug interactions are quite complex; ethanol administration to animals or man may affect the normal metabolism or the toxicity or teratogenicity of other foreign substances (Randall et al., 1977). These changes often involve the $P-450$ system, but much remains to be learned as to which isozymes are involved and whether induction of isozyme $3 \mathrm{a}$ (or a similar protein in species other than the rabbit) is responsible. Some examples of the effects of chronic alcohol consumption are increased hepatotoxicity of carbon tetrachloride (Hasumura et al., 1974; Traiger and Plaa, 1974), acetaminophen (Sato et al., 1981; McClain et al., 1980), and cocaine (Smith et al., 1981), and increased metabolism of methadone in rats (Borowsky and Lieber, 1978), hemotoxicity of inhaled benzene in peripheral blood, bone marrow, and splcen cells in mice (Baarson et al., 1982), and variable effects on drug metabolism and toxicity in human alcoholics (Pelkonen and Sotaniemi, 1982). An interesting example of a change in mitochondrial reactions following alcohol administration is the inhibition of $p$-nitroanisole demethylation resulting from the decreased availability of NADPH for NADPH-cytochrome $P-450$ reductase (Reinke et al., 1980).

\section{INDUCTION OF CYTOCHROME $P-450$ BY ETHANOL AND OTHER AGENTS}

As indicated above, the chronic administration of ethanol results in increased $P-450$ levels and increased rates of both ethanol and aniline oxidation in rat liver microsomes. Since enhancement of the activities of both of these substrates was also observed in hepatic microsomes following ethanol administration to rabbits (Koop et al., 1982), we have made use of the more convenient assay for aniline $p$-hydroxylation in testing a series of possible inducers of $P-450$ isozyme 3a. The results, which are given in Table 1, show that not only ethanol, but also trichloroethylene, $m$-xylene, pyrazole, and imidazole bring about enhanced activity toward aniline, whereas with aniline administration to the animals the findings are equivocal. Such experiments are complicated, of course, by possible effects of the compounds tested on rates of protein synthesis and heme incorporation into the cytochromes, as well as the question of whether some $P-450$ isozymes are repressed while another, isozyme $3 \mathrm{a}$, is induced. Experiments are in progress to obtain quantitative immunological evidence with $P-450_{\mathrm{LM}_{3 \mathrm{a}}}$ antibodies on the effectiveness of the induccrs. On the other hand, it appears clear that numerous compounds may serve as inducers of aniline hydroxylase and presumably, therefore, of alcohol oxidase activities associated with cytochrome $P-450$.

\section{CATALYTIC ACTIVITIES OF \\ CYTOCHROME P-450 ISOZYMES TOWARD ETHANOL $\Lambda$ ND OTHER SUBSTRATES}

The substrate preference of isozyme 3a was compared with that of the other P-450 iso- 
TABLE 1

ANILINE HYDROXYLASE ACTIVITY OF LIVER MICROSOMES FROM RABBITS TREATED WITH VARIOUS INDUCERS ${ }^{a}$

\begin{tabular}{lccc}
\hline & & \multicolumn{2}{c}{ Anilinc hydroxylasc activity } \\
\cline { 3 - 3 } $\begin{array}{c}\text { Compound } \\
\text { administered }\end{array}$ & $\begin{array}{c}P-450 \text { content } \\
\text { (nmol/mg protein) }\end{array}$ & $\mathrm{nmol} / \mathrm{min} / \mathrm{nmol} P-450$ & $\mathrm{nmol} / \mathrm{min} / \mathrm{mg}$ protein \\
\hline None & 2.5 & 0.13 & 0.38 \\
5,6-Benzoflavone & 3.4 & 0.10 & 0.34 \\
Trichloroethylene & 1.6 & 0.33 & 0.52 \\
Benzene & 3.2 & 0.10 & 0.32 \\
$m$-Xylene & 2.6 & 0.22 & 0.57 \\
Pyrazole & 3.6 & 0.30 & 1.08 \\
Aniline & 2.1 & 0.21 & 0.44 \\
Imidazole & 4.2 & 0.22 & 0.96 \\
Ethanol & 2.6 & 0.24 & 0.53 \\
\hline
\end{tabular}

${ }^{a}$ Aniline hydroxylation was determined in reaction mixtures which contained $2.5 \mathrm{~mm}$ aniline, $1.0 \mathrm{mg}$ of microsomal protein, $50 \mathrm{~mm}$ potassium phosphate buffer, $\mathrm{pH} 7.6$, and $1.0 \mathrm{~mm} \mathrm{NADPH}$ as the final addition. After a $30-\mathrm{min}$ incubation at $30^{\circ} \mathrm{C}$, the reaction was quenched by the addition of trichloroacetic acid, and the $p$-aminophenol was measured (Schenkman et al., 1967). In control experiments all components were present but trichloroacetic acid was added prior to NADPH.

zymes purified in this laboratory, as shown in Table 2 , in which the data are mostly taken from a previous report (Morgan et al., 1982). $P-450_{\mathrm{LM}_{3 \mathrm{a}}}$ had the highest activity of all isozymes examined toward aniline, ethanol, pro-

TABLE 2

CATAlytic ACTIVITY OF $P-450_{L_{3 a}}$ COMPARED TO OTHER ISOZYMES ${ }^{a}$

\begin{tabular}{lrrrrrrr}
\hline & \multicolumn{6}{c}{$\begin{array}{c}\text { Catalytic activity of isozymes } \\
\text { (nmol product formed/ } \\
\text { min/nmul }\end{array}$} \\
\cline { 2 - 8 } \multicolumn{1}{c}{ Substrate } & 2 & $3 \mathrm{a}$ & $3 \mathrm{~b}$ & $3 \mathrm{c}$ & 4 & 6 \\
\hline Methanol & 1.3 & 1.7 & 1.1 & 1.1 & 1.9 & \\
Ethanol & 3.6 & 10.8 & 1.2 & 1.6 & 4.4 & 3.0 \\
1-Propanol & 3.1 & 12.6 & 1.3 & 0.9 & 1.6 & \\
1-Butanol & 2.5 & 14.1 & 0.7 & 0.4 & 1.9 & \\
Aniline & 3.0 & 12.6 & 2.1 & 0.8 & 1.7 & 4.0 \\
Ethylmorphine & 4.6 & $<0.2^{b}$ & 4.9 & 3.0 & 2.6 & \\
Chlorcyclizine & 1.5 & 0.4 & 6.4 & 5.0 & 1.0 & \\
7-Ethoxycoumarin & 14.2 & 1.2 & 2.7 & 0 & 1.4 & 2.5 \\
\hline
\end{tabular}

\footnotetext{
${ }^{a}$ Incubation conditions for each substrate were optimized using the most active isozyme for that substrate. Alcohol concentrations were: methanol, $116 \mathrm{~mm}$; ethanol, $80 \mathrm{~mm}$; propanol, $40 \mathrm{~mm}$; and butanol, $22 \mathrm{~mm}$.

${ }^{b}$ This value is at the limit of detection in the assay used for ethylmorphine.
}

panol, and butanol and was 2.5 times as active as the next most active isozyme, $\mathbf{L M}_{4}$, with ethanol as substrate, and 5.5 times as active as $\mathrm{LM}_{2}$ toward butanol. In contrast, only low activities of all of the isozymes were observed with methanol as substrate. Another isozyme purified in this laboratory which we believe to be identical to form 6 , first described by Johnson and Muller-Eberhard (1977), had a turnover number of only 3.0 toward ethanol. The aforementioned ethanol-oxidizing activity of the reductase in the absence of $P-450$ may contribute to the observed rates of ethanol oxidation in the presence of the various isozymes, but whether the presence of $P-450$ has an effect on this intrinsic activity of the reductase is not known. If we assume no such effect and correct the $P-450$ activities for the reductase present, the ethanol-oxidizing activity of $\mathrm{LM}_{3 \mathrm{a}}$ relative to the other isozymes becomes 3-fold higher than that of $\mathrm{LM}_{2}$ and 4.5-fold higher than that of $\mathrm{LM}_{4} \cdot \mathrm{LM}_{3 \mathrm{~b}}$ and $\mathrm{LM}_{3 \mathrm{c}}$ do not have significantly higher activities than the reductase alone. $\mathrm{LM}_{3 \mathrm{a}}$ had no detectable activity toward ethylmorphine, whereas the other four isozymes all had similar but low activities with this substrate. The constitutive isozymes, $3 b$ and $3 c$ (Koop et al., 
1981) were the most active toward chlorcyclizine, and $3 \mathrm{a}$ was the least active. $\mathrm{LM}_{2}$ was about fivefold more active toward 7-ethoxycoumarin than $\mathrm{LM}_{3 \mathrm{~b}}$, the next most active isozyme, and $\mathrm{LM}_{3 \mathrm{a}}$ had only low but significant activity.

Liver microsomal $P-450$ isozymes are also known to metabolize a number of physiologically occurring compounds including medium chain length fatty acids, prostaglandins, and steroids. Probably the most extensively characterized of these reactions is the hydroxylation of testosterone. Isozyme $3 \mathrm{~b}$ exhibits the highest activity for testosterone hydroxylation followed in order by isozymes 6 , $4,3 \mathrm{c}$, and 3a. All these isozymes hydroxylate testosterone predominantly at the $6 \beta$ position and to a lesser extent at the $16 \alpha$ position. Isozyme 2 hydroxylates testosterone slowly, but, in contrast to the other isozymes, shows a preference for the $16 \alpha$ position. In addition to these two sites of attack, all six isozymes oxidize the $17 \beta$-hydroxy substituent to the ketone to form androstenedione, a biologically active metabolite. Isozyme $3 \mathrm{~b}$ exhibits the highest activity for this reaction followed in order by isozymes 4, 2, 3a, 6, and 3c. Similar activity has recently been reported for rat liver $P-450$ isozymes (Wood et al., 1983). From these results it is evident that steroid metabolism may be altered significantly by the administration of ethanol or other compounds which induce the liver microsomal $P-450$ system. Furthermore, ethanol and testosterone

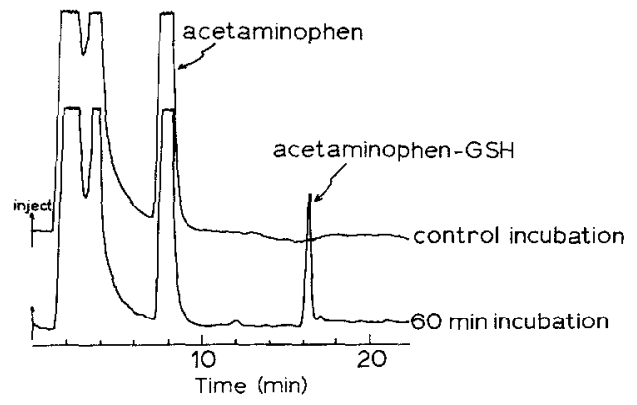

FIG. 1. Separation of glutathione conjugate from reactants by HPLC.

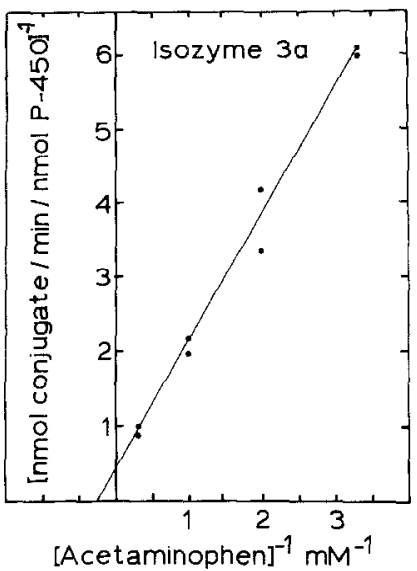

FIG. 2. Lineweaver-Burk plot, used to determine the $K_{m}$ of acetaminophen in formation of the glutathione conjugate.

would be expected to function as competitive substrates for the $P-450$ isozymes.

\section{ALCOHOL ADMINISTRATION AND ACETAMINOPHEN TOXICITY: ROLE OF CYTOCHROME $P-450$}

Our studies on the ethanol-inducible isozyme of liver microsomal cytochrome $P-450$ may also throw some light on toxicities of other foreign compounds as influenced by alcohol consumption. For example, in view of the reports of other investigators that the hepatotoxicity of acetaminophen is increased in ethanol-treated animals and the human alcoholic, we have determined the activity of the six available rabbit $P-450$ isozymes in the activation of the drug to give an intermediate which forms a conjugate with reduced glutathione (Morgan et al., 1983). Acetaminophen (Tylenol; $p$-hydroxyacetanilide), a widely used antipyretic and analgesic drug, is normally nontoxic but in large doses produces acute hepatic necrosis (Proudfoot and Wright, 1970; Prescott et al., 1971; Mitchell et al., 1973a). Metabolism of the drug by the liver microsomal $P-450$-containing oxygenase system results in the formation of an arylating species, thought to be $N$-acetyl-p-benzoqui- 
TABLE 3

ACTIVITIES OF $P$-450 ISOZYMES IN THE FoRMATION OF THE GLUTATHIONE-ACETAMINOPHEN CONJUGATE ${ }^{a}$

Activity of isozymes (nmol conjugate formed $/ \mathrm{min} / \mathrm{nmol} P-450$ )

\begin{tabular}{lrccccc}
\cline { 2 - 6 } \multicolumn{1}{c}{ System } & 2 & $3 \mathrm{a}$ & $3 \mathrm{~b}$ & $3 \mathrm{c}$ & 4 & 6 \\
\hline Complete & $<0.04$ & 2.16 & 0.14 & 0.22 & 3.67 & 1.44 \\
Complete + cytochrome $b_{5}$ & 0.07 & 2.09 & 0.14 & 0.40 & 5.50 & 0.94 \\
Complete, Tris buffer & & & & & & \\
$\quad$ substituted for phosphate & $<0.04$ & 4.17 & 0.22 & 0.14 & 4.86 & 0.90 \\
\hline
\end{tabular}

${ }^{a}$ This table is taken from Morgan et al. (1983). The complete system contained $0.2 \mu \mathrm{M} P-450_{\mathrm{LM}}, 0.6 \mu \mathrm{M}$ NADPHcytochrome $P-450$ reductase, $30 \mu \mathrm{g}$ of dilauroyl-GPC, $0.5 \mathrm{mM}$ glutathione, $12 \mathrm{~mm}$ acetaminophen, $50 \mathrm{~mm}$ potassium phosphate buffer, pH 7.6, and $1.0 \mathrm{mM}$ NADPH in a final volume of $1.0 \mathrm{ml}$. When present, cytochrome $b_{5}$ or Trischloride buffer, pH 7.6, were at concentrations of $0.2 \mu \mathrm{M}$ and $50 \mathrm{mM}$, respectively. After incubation at $30^{\circ} \mathrm{C}$ for 10 min, the reactions were quenched by the addition of $0.5 \mathrm{ml}$ of $3 \mathrm{~N}$ perchloric acid and analyzed by HPLC as described by Moldèus (1978). Values less than 0.04 are below the limits of accurate determination under the conditions of this assay.

noneimine (Potter et al., 1973; Corcoran et al., 1980; Nelson et al., 1980). This intermediate is conjugated with glutathione and excreted under normal conditions, but covalent binding to proteins occurs when cellular glutathione is depleted (Mitchell et al., 1973b; Moldèus, 1978). Pretreatment of animals with compounds which alter the mixed function oxidase system has a profound effect on the metabolism of acetaminophen (Mitchell et al., 1973a,b; Potter et al., 1973; Moldèus, 1978; Jollow et al., 1973). Increased hepatotoxicity of acetaminophen has been reported in human alcoholics (Proudfoot and Wright, 1970; Wright and Prescott, 1973; Emby and Fraser, 1977; McClain et al., 1980) and in ethanoltreated rats and mice with a concomitant increase in the hepatic metabolism of the drug and covalent binding of the metabolites to microsornal proteins (Proudfoot and Wright, 1970; Peterson et al., 1980; Sato et al., 1981).

The formation of the glutathione-acetaminophen conjugate was determined by HPLC as described by Moldèus (1978), with the results shown in Fig. 1. The product, a single metabolite peak absorbing at $250 \mathrm{~nm}$, had a retention time of 15 to $16 \mathrm{~min}$ and was well separated from the reactants. Formation of the conjugate required the presence of $P$ 450 , NADPH-cytochrome $P-450$ reductase, and NADPH, and was linear with respect to time up to $10 \mathrm{~min}$ at $30^{\circ} \mathrm{C}$. This assay was used to determine the effect of the acetaminophen concentration on the rate of the reaction. From the results presented as a Lineweaver-Burk plot in Fig. 2, the $\mathrm{Km}$ of acetaminophen was determined to be $5.9 \mathrm{mM}$.

The most active cytochrome in the generation of the glutathione-acetaminophen conjugate in the reconstituted system was isozyme 4 , as shown in Table 3. Isozymes $3 a$ and 6 were also quite active, while isozymes $3 \mathrm{~b}$ and $3 c$ were much less effective and isozyme 2 produced only trace amounts of the conjugate which were too small to be determined accurately. The effect of cytochrome $b_{5}$ was tested in view of the previous finding that it is required for prostaglandin hydroxylation by isozyme 2 (Vatsis et al., 1982) and the report of Miki et al. (1980) that $P-450_{\mathrm{B} 1}$, an isozyme apparently identical to isozyme $3 \mathrm{c}$ (Koop et al., 1981) requires cytochrome $b_{5}$ for the metabolism of some substrates. In the presence of cytochrome $b_{5}$, a measurable but still very low activity of isozyme 2 in acetaminophen conjugate formation was detected, and that of isozymes $3 \mathrm{c}$ and 4 was significantly increased; in contrast, the activity of isozyme 6 was inhibited, and that of $3 a$ and $3 b$ was not altered by the presence of cytochrome $b_{5}$. The activ- 
ities of isozymes $3 a, 3 b$, and 4 were substantially increased when Tris was substituted for phosphate buffer, whereas those of $3 \mathrm{c}$ and 6 were decreased. The reason for these effects is not known; despite the variable effects of both cytochrome $b_{5}$ and the buffer composition on the activities of the individual isozymes, the order of activities of the four most effective cytochromes was unchanged: $4>3$ a $>6>3 \mathrm{~b}$ or $3 \mathrm{c}$.

\section{ACKNOWLEDGMENTS}

This research was supported by Grant AA-06221 from the National Institute on Alcohol Abuse and Alcoholism. The authors are grateful to Dr. Edward T. Morgan for preliminary experiments on the induction of $P-450$ isozyme $3 a$.

\section{REFERENCES}

BaArson, K. A., Synder, C. A., Green, J. D., Sellakumar, A., Goldstein, B. D., AND Albert, R. E. (1982). The hematotoxic effects of inhaled benzene on peripheral blood, bone marrow, and spleen cells are increased by ingested ethanol. Toxicol. Appl. Pharmacol. 64, 393-404.

BOROWSKY, S. A., AND LIEBER, C. S. (1978). Interaction of methadone and ethanol metabolism. J. Pharmacol. Exp. Ther. 207, 123-129.

Brentzel, H. J., AND Thurman, R. G. (1977). Quantitation of pathways responsible for NADPH-dependent methanol, ethanol, and butanol oxidation by hepatic microsomes. In Alcohol and Aldehyde Metabolizing Systems (R. G. Thurman, J. R. Williamson, H. R. Drott, and B. Chance, eds.), Vol. 2, pp. 373-380. Academic Press, New York.

CHANCE, B. (1947). An intermediate compound in the catalase-hydrogen peroxide reaction. Acta Chem. Scand. 1, 236-267.

Chance, B., Oshino, N., Sugano, T., and Jamieson, D. (1974). Role of catalase in ethanol metabolism. In Alcohol and Aldehyde Metabolizing Systems (R. G. Thurman, T. Yonetani, J. R. Williamson, and B. Chance, eds.), pp. 169-182. Academic Press, New York.

COMAI, K., AND GAYlor, J. L. (1973). Existence and separation of three forms of cytochrome P-450 from rat liver microsomes. J. Biol. Chem. 248, 4947-4955.

Coon, M. J. (1981). Drug metabolism by cytochrome P450: Progress and perspectives. The 1980 Bernard B. Brodie Award Lecture. Drug Metab. Dispos. 9, 1-4.

COON, M. J., CONNEY, A. H., ESTABRoOK, R. W., GELBOIN, H. V., Gillet TE, J. R., AND O'BRIEN, P. J. (eds.) (1980a). Microsomes, Drug Oxidations, and Chemical
Carcinogenesis. Proceedings of the Fourth International Symposium, Ann Arbor, 1979, Vol. 1 and 2. Academic Press, New York.

CoOn, M. J., AND KoOP, D. R. (1983). P-450 oxygenases in lipid transformation. In: The Enzymes, (P. D. Boyer, ed.), in press.

COON, M. J., KoOP, D. R., AND MORGAN, E. T. (1983). Alcohol oxidation by isozyme $3 \mathrm{a}$ of liver microsomal cytochrome P-450. Pharmacol. Biochem. Behav. 18, $177-180$.

CoOn, M. J., Persson, A. V., ANd French, J. S. (1980b). On the possible relationship of cytochrome P-450 to alcohol metabolism: fundamental aspects of the microsomal hydroxylation system, including properties and interactions of the components. In Alcohol and Aldehyde Metabolizing Systems (R. G. Thurman, ed.), Vol. 4, pp. 11-22. Plenum, New York.

CoOn, M. J., AND Whrre, R. E. (1980). Cytochrome P450 , a versatile catalyst in monooxygenation reactions. In Metal Ion Activation of Dioxygen (T. G. Spiro, ed.), pp. 73-123. Wiley, New York.

Corcoran, G. B., Mitchell, J. R., Vaishav, Y. N., AND HORNING, E. C. (1980). Evidence that acetaminophen and $\mathrm{N}$-hydroxyacetaminophen form a common arylating intermediate, $\mathrm{N}$-acetyl- $p$-benzoquinoneimine. Mol. Pharmacol. 18, 536-542.

DeITRICH, R. A., AND Collins, A. C. (1977). Pharmacogenetics of alcoholism. In Alcohol and OpiatesNeurochemical and Behavioral Mechanisms (K. Blum, cd.), pp. 109-139. Academic Press, New York.

EMBY, D. J., AND FrASER, B. N. (1977). Hepatotoxicity of paracetamol enhanced by ingestion of alcohol. $S$. Afr. Med. J. 51, 208-209.

ESTABROOK, R. W. (1974). The role of catalase in microsomal ethanol oxidation. In Alcohol and Aldehyde Metabolizing Systems, (R. G. Thurman, T. Yonetani, J. R. Williamson, and B. Chance, eds.), pp. 559-563. Academic Press, New York.

GUENGERICH, F. P. (1979). Isolation and purification of cytochrome P-450, and the existence of multiple forms. Pharmacol. Ther. A 6, 99-121.

Gustafsson, J.-A., CARlstedT-Duke, J., MODE, A., AND RAFTER, J., eds. (1980). Biochemistry, Biophysics, and Regulation of Cytochrome P-450. Proceedings of the Third European Meeting, Saltsjöbaden. Elsevier/NorthHolland, Amsterdam.

HASUMURA, Y., TeSChKe, R., AND LIEBER, C. S. (1974). Increased carbon tetrachloride hepatotoxicity, and its mechanism, after chronic ethanol consumption. Gastroenterology 66, 415-422.

INGELMAN-SUNDBERG, M., AND JOHANSSON, I. (1981). The mechanism of cytochrome P-450-dependent oxidation of ethanol in reconstituted membrane vesicles. J. Biol. Chem. 256, 6321-6326.

ISERI, O. A., LieBer, C. S., AND GoTTLIEB, L. S. (1966). The ultrastructure of fatty liver induced by prolonged ethanol ingestion. Amer. J. Path. 48, 535-545. 
ISHII, H., JOLY, J.-G., AND LIEBER, C. S. (1973). Effects of ethanol on the amount and enzyme activities of hepatic rough and smooth microsomal membranes. Biochim. Biophys. Acta 291, 411-420.

IsSElBACHER, K. J., AND CARTER, E. A. (1974). Peroxidatic oxidation of ethanol by microsomes. In Alcohol and Aldehyde Metabolizing Systems, (R. G. Thurman, T. Yonetani, J. R. Williamson, and B. Chance, eds.), pp. 271-286. Academic Press, New York.

JOHNSON, E. F., AND MULLER-EBERHARD, U. (1977). Multiple forms of cytochrome P-450: resolution and purification of rabbit liver aryl hydrocarbon hydroxylase. Biochem. Biophys. Res. Commun. 76, 644-651.

Jollow, D. J., MitChell, J. R., POTTER, W. Z., DAvis, D. C., GillejTe, J. R., AND BRodie, B. B. (1973). Acetaminophen-induced hepatic necrosis. II. Role of covalent binding in vivo. J. Pharmacol Exp. Ther. 187, 195-202.

Keilin, D., and Hartree, E. F. (1945). Properties of catalase. Catalysis of coupled oxidation of alcohols. Biochem. J. 39, 293-301.

KoOp, D. R., Morgan, E. T., TARR, G. E., And CoON, M. J. (1982). Purification and characterization of a unique isozyme of cytochrome P-450 from liver microsomes of ethanol-treated rabbits. J. Biol. Chem. 257, 8472-8480.

Koop, D. R., Persson, A. V., ANd CoOn, M. J. (1981). Properties of electrophoretically homogeneous constitutive forms of liver microsomal cytochrome P-450. $J$. Biol. Chem. 256, 10704-10711.

LAZAROW, P. B. (1977). Metabolism of $\mathrm{H}_{2} \mathrm{O}_{2}$ and fatty acids by rat liver peroxisomes: implications for ethanol detoxification. In Alcohol and Aldehyde Metabolizing Systems (R. G. Thurman, J. R. Williamson, H. R. Drott, and B. Chance, eds.), Vol. 2, pp. 275-289. Academic Press, New York.

LIEBER, C. S. (1980). Interaction of ethanol with drug toxicity. Amer. J. Gastroenterol. 74, 313-320.

L.IFRFR, C. S., AND DECARLI, L. M. (1970). Hepatic microsomal ethanol-oxidizing system: In vitro characteristics and adaptive properties in vivo. J. Biol. Chem. 245, 2505-2512.

Lieber, C. S., Teschke, R., Hasumura, Y., AND DeCARLI, L. M. (1974). Interaction of ethanol with liver microsomes. In Alcohol and Aldehyde Metabolizing Systems (R. G. Thurman, T. Yonetani, J. R. Williamson, and B. Chance, eds.), pp. 243-256. Academic Press, New York.

LU, A. Y. H., AND WEST, S. B. (1980). Multiplicity of mammalian microsomal cytochromes P-450. Pharmacol. Rev. 31, 277-295.

MajChrowicz, E., AND Noble, E. P., eds. (1979). Biochemistry and Pharmacology of Ethanol, Vol. 1. Plenum, New York.

McClain, C. J., Kromhout, J. P., Peterson, F. J., And HolTzMAN, J. L. (1980). Potentiation of acetaminophen hepatotoxicity by alcohol. J. Amer. Med. Assoc. 244, $251-253$.

MEZEY, E. (1976). Ethanol metabolism and ethanol-drug interactions. Biochem. Pharmacol. 25, 869-875.

Mezey, E., Potter, J. J., AND Reed, W. D. (1973). Ethanol oxidation by a component of liver microsomes rich in cytochrome P-450. J. Biol. Chem. 248, 11831187.

Miki, N., SugiYama, T., ANd Yamano, T. (1980). Purification and characterization of cytochrome P-450 with high affinity for cytochrome $b_{5}$. J. Biochem. (Tokyo) 88, 307-316.

Mitchell, J. R., Jollow, D. J., Potter, W. Z., DAVID, D. C., GILlette, J. R., AND BRodie, B. B. (1973a). Acetaminophen-induced hepatic necrosis. I. Role of drug metabolism. J. Pharmacol. Exp. Ther. 187, 185-194.

MitChell, J. R., Jollow, D. J., Potter, W. Z., GilLETTE, J. R., AND BRodIE, B. B. (1973b). Acetaminophen-induced hepatic necrosis. IV. Protective role of glutathione. J. Pharmacol. Exp. Ther. 187, 211-217.

Mrwa, G. T., Levin, W., Thomas, P. E., AND LU, A. Y. H. (1977). Evidence for the direct involvement of hepatic cytochrome P-450 in ethanol metabolism. In Alcohol and Aldehyde Metabolizing Systems (R. G. Thurman, J. R. Williamson, H. R. Drott, and B. Chance, eds.), Vol. 2, pp. 323-334. Academic Press, New York.

Miwa, G. T., LeVIN, W., Thomas, P. E., AND LU, A. Y. H. (1978). The direct oxidation of ethanol by a catalase- and alcohol dehydrogenase-free reconstituted system containing cytochrome P-450. Arch. Biochem. Biophys. 187, 464-475.

MOLDÈUS, P. (1978). Paracetamol metabolism and toxicity in isolated hepatocytes from rat and mouse. Biochem. Pharmacol. 27, 2859-2863.

Morgan, E. T., Devine, M., And SketT, P. (1981). Changes in the rat hepatic mixed function oxidase system associated with chronic ethanol vapor inhalation. Biochem. Pharmacol. 30, 595-600.

MORGAN, E. T., KoOP, D. R., AND COON, M. J. (1982). Catalytic activity of cytochrome P-450 isozyme $3 \mathrm{a}$ isolated from liver microsomes of ethanol-treated rabbits. J. Biol. Chem. 257, 13951-13957.

Morgan, E. T., KoOp, D. R., AND CoON, M. J. (1983). Comparison of six rabbit liver cytochrome P-450 isozymes in formation of a reactive metabolite of acetaminophen. Biochem. Biophys. Res. Commun. 112, $8-13$.

Mungikar, A. M., Hetu, C., AND Joly, J.-G. (1980). Ethanol-inducible liver cytochrome P-450 in the rat: Relative specificity for ethanol oxidation activity in vitro. In Alcohol and Aldehyde Metabolizing Systems (R. G. Thurman, ed.), Vol. 4, pp. 51-56. Plenum, New York.

Nelson, S. D., Forte, A. J., AND Dahlin, D. C. (1980). Lack of evidence for N-hydroxyacetaminophen as a reactive metabolite of acetaminophen in vitro. Biochem. Pharmacol. 29, 1617-1620. 
Oshino, N., Oshino, R., and Chance, B. (1974). The properties of catalase "peroxidatic" reaction and its relationship to microsomal methanol oxidation. In Alcohol and Aldehyde Metabolizing Systems (R. G. Thurman, T. Yonetani, J. R. Williamson, and B. Chance, eds.), pp. 231-242. Academic Press, New York.

OHNISHI, K., AND LIEBER, C. S. (1977a). Reconstitution of the microsomal ethanol-oxidizing system. Qualitative and quantitative changes of cytochrome P-450 after chronic alcohol consumption. J. Biol. Chem. 252, 71247131.

OHNISHI, K., AND LIEBER, C. S. (1977b). Reconstitution of the hepatic microsomal ethanol oxidizing system (MEOS) in control rats and after ethanol feeding. In Alcohol and Aldehyde Metabolizing Systems (R. G. Thurman, J. R. Williamson, H. R. Drott, and B. Chance, eds.), Vol. 2, pp. 341-350. Academic Press, New York.

Pelkonen, O., And Sotaniemi, E. (1982). Drug metabolism in alcoholics. Pharmacol. Ther, 16, 261-268.

Peterson, F. J., Holloway, D. E., Erickson, R. R., Duquette, P. H., MCClain, C. J., AND Holtzman, J. L. (1980). Ethanol induction of acetaminophen toxicity and metabolism. Life Sci. 27, 1705-1711.

Potter, W. Z., Davis, D. C., Mitchell, J. R., Jollow, D. J., Gillette, J. R., AND BRodie, B. B. (1973). Acetaminophen-induced hepatic necrosis. III. Cytochrome P-450-mediated covalent binding in vitro. $J$. Pharmacol. Exp. Ther. 187, 203-210.

PrescotT, L. F., Wright, N., Roscoe, P., AND Brown, S. S. (1971). Plasma-paracetamol half-life and hepatic necrosis in patients with paracetamol overdosage. Lancet 1, 519-522.

ProudroOt, ^. T., AND WRIGHT, N. (1970). ^cute paracetamol poisoning. Brit. Med. J. 3, 557-558.

Randall, C. L., Taylor, W. J., TABakofF, B., AND WALKER, D. W. (1977). Ethanol as a teratogen. In Alcohol and Aldehyde Metabolizing Systems (R. G. Thurman, J. R. Williamson, H. R. Drott, and B. Chance, eds.), Vol. 3, pp. 659-670. Academic Press, New York.

Reinke, L. A., Belinsky, S. A., Kauffman, F. C., AND THURMAN, R. G. (1980). Mechanism of inhibition of mixed-function oxidation by ethanol. In Alcohol and Aldehyde Metabolizing Systems (R. G. Thurman, ed.), Vol. 4, pp. 151-161. Plenum, New York.

Rutain, E., Hempei, J., Pietruszko, R., ANd CederBAUM, A. I. (1977). Ethanol-oxidizing enzymes in transplantable hepatocellular carcinoma. In Alcohol and Aldehyde Metabolizing Systems (R. G. Thurman, J. R. Williamson, H. R. Drott, and B. Chance, eds.), Vol. 3, pp. 219-229. Academic Press, New York.

Sato, C., Matsuda, Y., ANd Lieber, C. S. (1981). Increased hepatotoxicity of acetaminophen after chronic ethanol consumption in the rat. Gastroenterology $\mathbf{8 0}$, 140-148.

SATO, R., AND Kato, R. (1982). Microsomes, Drug Oxidations, and Drug Toxicity. Proceedings of the Fifth
International Symposium, Tokyo, 1981, Japan Scientific Societies Press, Tokyo.

SCHENKMAN, J. B., REMMER, H., AND EstabroOK, R. W. (1967). Spectral studies of drug interaction with microsomal cytochrome. Mol. Pharmacol. 3, 113-123.

Sharma, R. N., Cameron, R. G., Farber, E., Griffin, M. J., JOLY, J.-G., AND MurRay, R. K. (1979). Multiplicity of induction patterns of rat liver microsomal mono-oxygenases and other polypeptides produced by administration of various xenobiotics. Biochem. $J . \mathbf{1 8 2}$, 317-327

Sinclair, J. F., Sinclair, P. R., Smith, E. L., Bement, W. J., POMEROY, J., AND BONKOWSKY, H. (1981). Ethanol-mediated increase in cytochrome P-450 in cultured hepatocytes. Biochem. Pharmacol. 30, 2805-2809.

Smith, A. C., Freeman, R. N., and Harbison, R. D. (1981). Ethanol enhancement of cocaine-induced hepatotoxicity. Biochem. Pharmacol. 30, 451-453.

SMITH, M. E. (1961). Interrelations in ethanol and methanol metabolism. I. Pharmacol. Exp. Ther. 134, 233-237.

Teschke, R., Moreno, F., AND PeTrides, A. S. (1981). Hepatic microsomal ethanol oxidizing system (MEOS): Respective roles of ethanol and carbohydrates for the enhanced activity after chronic alcohol consumption. Biochem. Pharmacol. 30, 1745-1751.

THEORELL, H. (1974). Historical aspects of physiological alcohol combustion. In Alcohol and Aldehyde Metabolizing Systems (R. G. Thurman, T. Yonetani, J. R. Williamson, and B. Chance, eds.), pp. 1-6. Academic Press, New York.

Thurman, R. G., Hesse, S., AND Scholz, R. (1974). The role of NADPH-dependent hydrogen peroxide formation and catalase in hepatic microsomal ethanol oxidation. In Alcohol and Aldehyde Metabolizing Systems (R. G. Thurman, T. Yonetani, J. R. Williamson, and B. Chance, eds.), pp. 257-270. Academic Press, New York.

TSUJI, H., MuTA, E., AND ULLRICH, V. (1980). Separation and purification of liver microsomal monooxygenases from induced and untreated pigs. Hoppe-Seyler's $Z$. Physiol. Chem. 361, 681-696.

Traiger, G. J., and PlaA, G. L. (1972). Relationship of alcohol metabolism to the potentiation of $\mathrm{CCl}_{4}$ hepatotoxicity induced by aliphatic alcohols. J. Pharmacol. Exp. Ther. 183, 481-488

VATSIS, K. P., ChanCE, B., AND SCHUlman, M. P. (1977). Studies on the characterization of the enzyme components participating in the hepatic-microsomal oxidation of aliphatic alcohols. In Alcohol and Aldehyde Metabolizing Systems (R. G. Thurman, J. R. Williamson, H. R. Drott, and B. Chance, eds.), Vol. 2, pp. 361372. Academic Press, New York.

VATSIS, K. P., AND COON, M. J. (1977). On the question of whether cytochrome P-450 catalyzes ethanol oxidation: Studies with purified forms of the cytochrome from rabbit liver microsomes. In Alcohol and Aldehyde 
Metabolizing Systems (R. G. Thurman, J. R. Williamson, H. R. Drott, and B. Chance, eds.), Vol. 2, pp. 307322. Academic Press, New York.

VATSIS, K. P., AND SChULMAN, M. P. (1974). "Acatalatic" hepatic microsomes metabolize drugs but not ethanol. In Alcohol and Aldehyde Metabolizing Systems (R. G. Thurman, T. Yonetani, J. R. Williamson, and B. Chance, eds.), pp. 287-298. Academic Press, New York.

VATSIS, K. P., AND SChulman, M. P. (1977). Catalase and alcohol dehydrogenase-mediated oxidation of ethanol in hepatic microsomes of acatalasemic mice. In Alcohol and Aldehyde Metabolizing Systems (R. G. Thurman, J. R. Williamson, H. R. Drott, and B. Chance, eds.), Vol. 2, pp. 381-392. Academic Press, New York.

VATSIS, K. P., Theoharides, A. D., KuPFer, D., AND CoON, M. J. (1982). Hydroxylation of prostaglandins by inducible enzymes of rabbit liver microsomal cytochrome P-450. Participation of cytochrome $b_{5} . J$. Biol. Chem. 257, 11221-11229.

VILLENECVE, J..P., MAVIER, P., AND JOLY, J.-G. (1976). Ethanol-induced cytochrome P-450: Catalytic activity after partial purification. Biochem. Biophys. Res. Commun. 70, 723-728.

WERringloer, J., Chacos, N., AND ESTABRoOK, R. W. (1977). Microsomal electron transport reactions: the formation and utilization of hydrogen peroxide as related to alcohol metabolism. In Alcohol and Aldehyde Metabolizing Systems (R. G. Thurman, J. R. Williamson, H. R. Drott, and B. Chance, eds.), Vol. 2, pp. 351360. Academic Press, New York.

Wood, A. W., Ryan, D. E., Thomas, P. E., AND LeVin, W. (1983). Regio- and stereoselective metabolism of two $\mathrm{C}_{19}$ steroids by five highly purified and reconstituted rat hepatic cytochrome P-450 isozymes. J. Biol. Chem. 258, 8839-8847.

WHITE, R. E., AND COON, M. J. (1980). Oxygen activation by cytochrome P-450. Annu. Rev. Biochem. 49, 315-356.

Wright, N., AND PrescotT, L. F. (1973). Potentiation by previous drug therapy of hepatotoxicity following paracetamol overdosage. Scot. Med. J. 18, 56-58. 